\title{
Toxic "ictal" confusion in middle age: treatment with benzodiazepines
}

\author{
B VAN SWEDEN \\ From the Ghent University Medical Centre, Department of Psychiatry, Ghent, Belgium
}

SUMMARY In adult and elderly non-epileptic subjects psychoactive drugs may cause an altered state of consciousness and repetitive irritative EEG discharges. The neurotoxic pathogenesis of this drug-induced confusion and the differentiation from absence status are discussed. Dramatic relief by intravenous benzodiazepines is detailed. Recovery is complete and prognosis is excellent on withdrawal of the offending drug.

The acute confusional states are one of the most common psychological syndromes, and are caused by a physiological disturbance rather than by a structural brain disease.' When patients present with prominent mental confusion without clinical convulsive phenomena, but with continuous or discontinuous runs of EEG discharges, they may be suspected of having an epileptic condition. There is a small group of adult or elderly patients who present with such confusional states and EEGs showing unexpectedly repetitive EEG discharges. This phenomenon has been reported but is still not clearly understood..$^{2-5}$ It may be drug-induced, as emphasised in the present communication, and reversed by intravenous benzodiazepines.

\section{Clinical material (table 1)}

The patients were admitted to the psychiatric ward for psychomotor agitation (case no 1), paranoid delusions and acoustic hallucinations (case no 2), attempted suicide with concomitant gastric bleeding (case no 3), and depression (case no 4). None of our patients had a personal or family history of an epileptic condition. Only one patient showed signs of pre-existing brain damage (case no 3 , congenital mental impairment without a personal or family history of

Address for reprint requests: B Van Sweden, Ghent University Medical Centre, EEG-Laboratory, Dept of Psychiatry, 185 De Pintelaan, 9000 Ghent, Belgium.

Received 12 June 1984 and in revised form 27 September 1984. Accepted 10 October 1984 seizure disorder) which could have predisposed to a more $\infty$ severe reaction to a noxious agent. The drugs involved if $\mathrm{G}$ our cases are aminoalkylphenothiazine derivatives (cased nos 1,2 ), a dibenzazepine derivative (case no 2), a his $N$ tamine $\mathbf{H}_{2}$-receptor antagonist (case no 3 ) and a diberg zodiazepine derivative (case no 4 ). The clinical syndrone $\rightarrow$ presented by our patients consisted of vegetative disorder $>$ such as flushing, pallor, sweating, nausea and labile tensiog 욧 (cases nos 1, 2, 3), myoclonic jerking (cases nos 1, 2, 3 $\vec{A}$ tonic fits (case no 3 ), generalised tonic-clonic fits (cases no 2,3 ) and altered states of consciousness (cases nos 1-4) The clinical features occurred after 7 to 12 days of drug treatment. The EEG-recordings, which had been normal on or before admission (fig A), were severely altered in all cases. The EEG recordings of our four patients showed repetitive EEG discharges which were rhythmically repeated over periods of several seconds throughout the entire EEG recording. In two cases repetitive polyspike-andwave discharges at 1-2 $\mathrm{Hz}$ were observed, predominantly over the central regions (cases nos 1,4) (fig B). In two other cases the EEG discharges were more compound and lateralised (cases nos 2, 3) (fig D). However, neurological examination and complementary investigations including CT scan were normal in all cases. The outcome in all four cases was excellent. Both the EEG discharges and clinical features disappeared within minutes following intravenous clonazepam treatment (fig C, D). The clearing of consciousness and disappearance of epileptic phenomena proved to be permanent following discontinuance of the offending drugs. Most patients had a clinical follow-up of several years, without recurrence of the condition or any- $D$ thing resembling it. Two of our patients (cases nos 1, 4) 을. presented with signs of mild toxic hepatic dysfunction a few $\overline{\mathrm{N}}$ weeks after CNS involvement but the fact that the latter $\Omega$ preceded the metabolic dysfunction, suggests that there was no direct relationship. 
Table Electroclinical features related to outcome and drugs involved

\begin{tabular}{|c|c|c|c|c|}
\hline & & & Electroclinical features & Outcome \\
\hline 1 & $\begin{array}{l}\text { B.E. age } \\
38 \mathrm{yr}\end{array}$ & $\begin{array}{l}\text { chlorpromazine } 75 \mathrm{mg} \\
\text { promethazine } 75 \mathrm{mg} \\
\text { im daily for } 7 \text { days }\end{array}$ & $\begin{array}{l}\text { stupor, myoclonic jerking } \\
\text { diffuse low-voltage slow-wave activity } \\
\text { intermittent runs of bifrontocentral } \\
\text { discharges at } 1-2 \mathrm{~Hz}\end{array}$ & $\begin{array}{l}\text { clonazepam } 1 \mathrm{mg} \text { iv } \\
\text { clearing stupor, partial } \\
\text { amnesia, disappearance } \\
\text { myoclonias } \\
\text { no recurrence }\end{array}$ \\
\hline 2 & $\begin{array}{l}\text { V.A.M. age } \\
39 \text { yr }\end{array}$ & $\begin{array}{l}\text { levomepromazine } 75 \mathrm{mg} \\
\text { imipramine } 75 \mathrm{mg} \\
\text { im daily for } 8 \text { days }\end{array}$ & $\begin{array}{l}\text { stupor, myoclonias, tonic-clonic seizure } \\
\text { diffuse low-voltage slow-wave activity } \\
\text { PLEDs at } 1-2 \mathrm{~Hz} \text { in the right temporo- } \\
\text { occipital regions }\end{array}$ & $\begin{array}{l}\text { clonazepam } 1 \mathrm{mg} \text { iv } \\
\text { clearing stupor within minutes, } \\
\text { amnesia no recurrence }\end{array}$ \\
\hline 3 & $\begin{array}{l}\text { B.M.L. age } \\
46 \mathrm{yr}\end{array}$ & $\begin{array}{l}\text { cimetidine } 1600 \mathrm{mg} \\
\text { daily for } 12 \text { days }\end{array}$ & $\begin{array}{l}\text { confusion, agitation, flushing, myoclonias, } \\
\text { tonic tonic-clonic seizures } \\
\text { diffuse slow-wave activity, intermittent } \\
\text { runs compound sharp discharges at } 1-2 \mathrm{~Hz} \\
\text { starting over the left hemisphere }\end{array}$ & $\begin{array}{l}\text { clonazepam } 1 \mathrm{mg} \text { iv (drip for } 2 \text { days) } \\
\text { clearing confusional state stop epileptic } \\
\text { phenomena }\end{array}$ \\
\hline 4 & $\underset{57 \text { yr }}{\text { S.L. age }}$ & $\begin{array}{l}\text { dibenzepine } \mathrm{HCl} 240 \mathrm{mg} \\
\text { daily for } 8 \text { days }\end{array}$ & $\begin{array}{l}\text { stupor, twice loss of consciousness } \\
\text { continuous repetitive diffuse polyspike- } \\
\text { wave discharge at } 1-2 \mathrm{~Hz}(\mathrm{fig} \mathrm{A}, \mathrm{B})\end{array}$ & $\begin{array}{l}\text { clonezepam } 1 \mathrm{mg} \text { iv clearing sensorium } \\
\text { disappearance EEG discharges within } \\
\text { minutes (fig C) }\end{array}$ \\
\hline
\end{tabular}

PLEDs = periodic lateralised epileptiform discharges .

\section{Discussion}

As the symptomatology of the acute confusional state follows a surprisingly constant pattern despite a variety of causes, complementary investigations such as the EEG, are particularly valuable. ${ }^{67}$ Although all our EEG records were severely abnormal, none of our middle-aged confused patients had a history of epilepsy or suffered a recurrence of a similar electro-clinical condition. Continuous or discontinuous repetitive EEG discharges were a common EEG feature in our observations. ${ }^{8} \quad$ Generalised bilaterally synchronous paroxysmal discharges usually indicate diffuse encephalopathy with predominantly grey matter involvement. ${ }^{9}$ However, cases presenting with similar electro-clinical features have been claimed to be related to petit mal status presenting in middle age. ${ }^{25}$ Although this syndrome may be reactivated or occur de novo in adults or the elderly, ${ }^{10-14}$ this relationship is rightly questioned by Gibberd. ${ }^{15}$ In our opinion the electro-clinical features of our cases result from other pathogenetic disorders and should not be considered as the expressions of an atypical course of generalised epilepsy. Moreover, the longterm good prognosis did not herald the onset of Jacob-Creutzfeldt disease or other degenerative disorders. Lateralised repetitive compound EEG discharges may occur in patients presenting an altered state of consciousness and no history of epilepsy. However, evidence of an acute or progressive cerebral lesion was not found. ${ }^{16-18}$

The clinical syndrome appeared within 1 week after administration of the noxious psychotropic drugs and disappeared on drug-withdrawal. For ethical reasons "EEG activating" drugs were not reinstituted. The clinical signs were not due to a deterioration of the mental dysfunction present before drug treatment. This correlation in time between drug administration and CNS involvement remains the strongest evidence that the observed clinical syndrome was drug-related. The precipitation of confusion and myoclonic jerkings by psychotropic drugs has been recognised by other authors. ${ }^{19-22}$ Dysfunction of serotonergic and cholinergic transmission has been claimed to underly drug-induced confusion and myoclonus. $^{23-25}$ The pharmacological properties of the drugs involved in our observation suggest dysfunction of alpha-adrenergic and histaminergic transmission in patients presenting the above-mentioned electro-clinical features. However, patients with neurotoxic cerebral impairment probably show complex disturbances of many interconnected transmitter systems at different levels of the neuraxis. Moreover, similar electro-clinical observations have been reported. In several of the cases presented by Ellis and Lee, ${ }^{3}$ toxic (cases nos 1,5 ) or psychiatric dysfunction (cases nos $3,4,6$ ) preceded the clinical confusional state. The same applies to the patient presented by Aguglia et al..$^{5}$ Many arguments indicate that in adult or elderly patients a drug-induced confusional state may occur, electroencephalographically characterised by repetitive irritative "ictal" EEG-discharges.

The clinical condition of all four patients dramatically improved after iv injection of clonazepam. Both confusional states and the irritative EEG discharges disappeared within minutes. The patients of Ellis and Lee, ${ }^{3}$ Schwartz and Scott ${ }^{2}$ and the patient referred to by Aguglia et al,,$^{5}$ showed similar improvement after iv administration of diazepam. As benzodiazepinès enhance polysynaptic inhibition processes and GABA-ergic inhibition at all levels of the brain, the prominent therapeutic effect of benzodiazepines in general and clonazepam in par- 
(a)

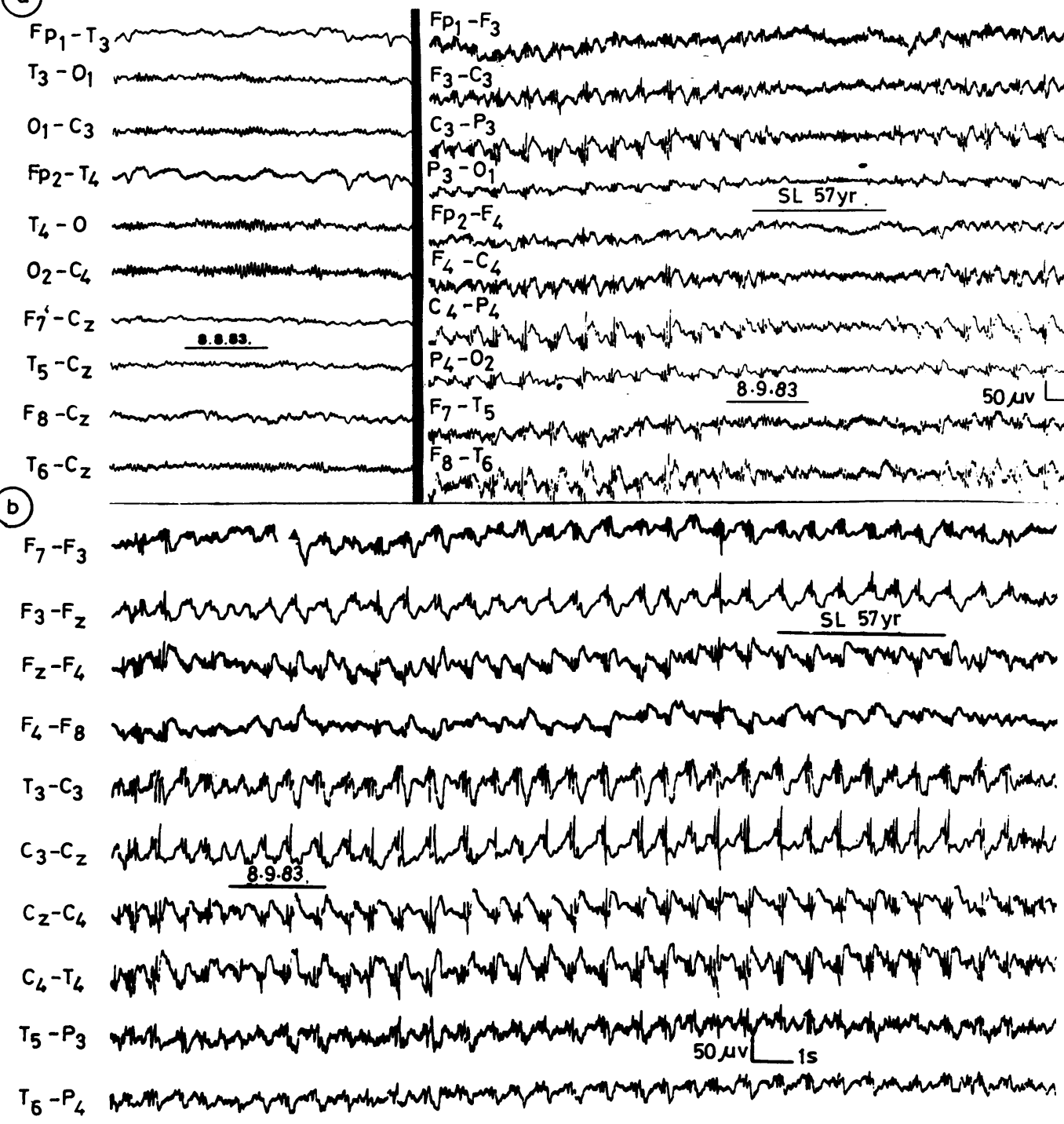

Fig 1 On admission the EEG of case no. 4 shows a physiological alpha-rhythm, the patient is well-oriented and responsive (A). Following dibenzepine $\mathrm{HCl} 240 \mathrm{mg}$ a day for 1 week continuous diffuse bilateral repetitive high voltage polyspike wave discharges at 1-2 $\mathrm{Hz}$ prevail over the central regions $(B)$, correlating with stupor, disorientation and mutism. No concomitant clinical convulsive signs are noticed. Immediately after iv injection of $1 \mathrm{mg}$ clonazepam (arrow) fragmentation and attenuation of repetitive discharges is noticed $(C)$. Three minutes later an alpha-background activity within physiological range appears. The patient is responsive and oriented. Clinical stupor in case no. $2(D)$ is characterized by PLED's at 1-2 Hz in the right temporo-occipital regions. The patient has received a combination of levomepromazine 75 $\mathrm{mg}$ and imipramine $75 \mathrm{mg}$ for 8 days. The irritative discharges disappear following iv injection of $1 \mathrm{mg}$ clonazepam. 
(c)

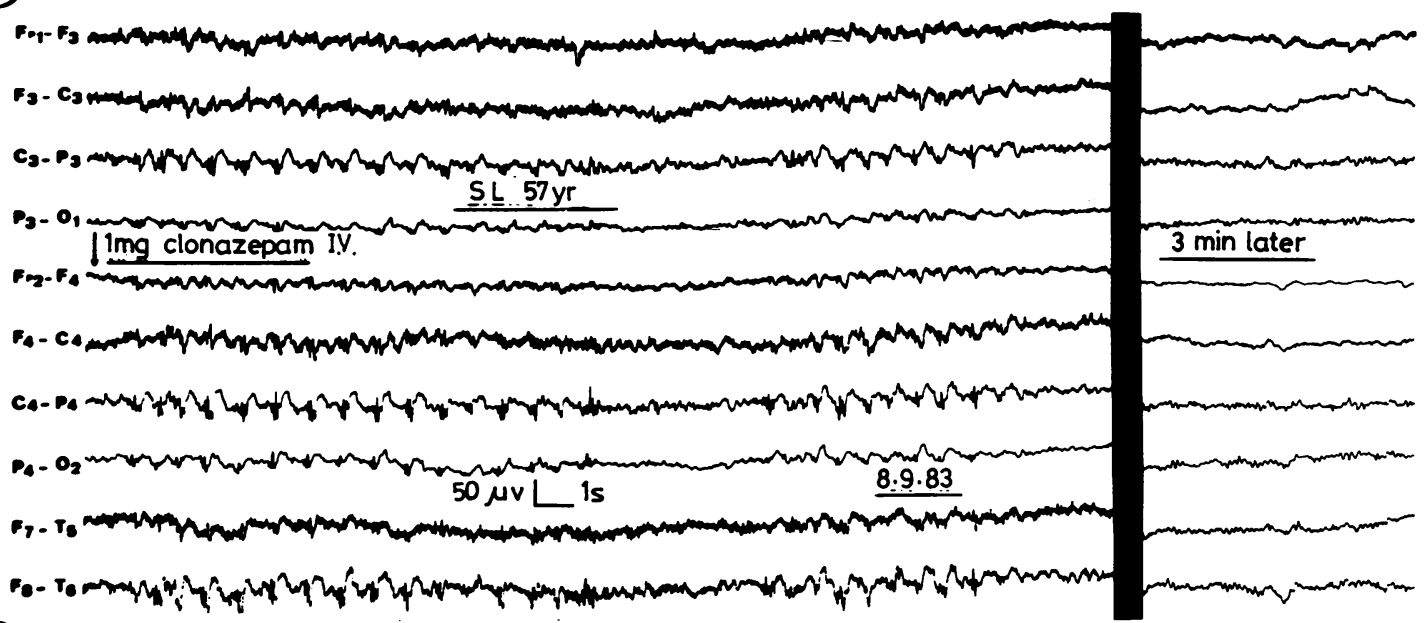

(d)

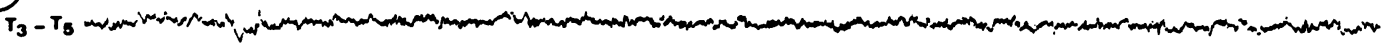

$T_{5}-0$, J.img clonazepaim I.V.

$\mathrm{O}_{1}-\mathrm{O}_{2}$ rid

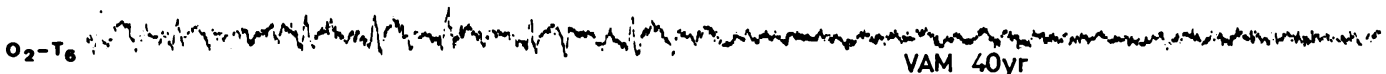

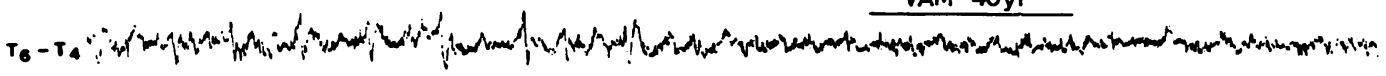

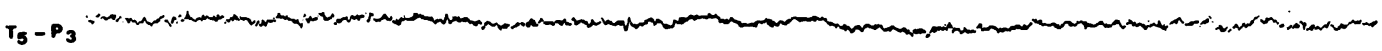

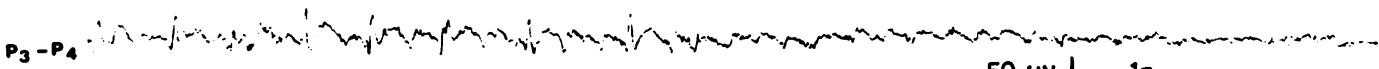

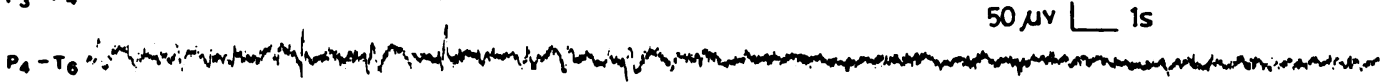

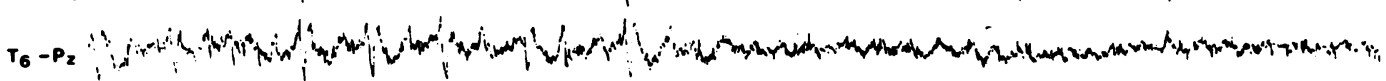

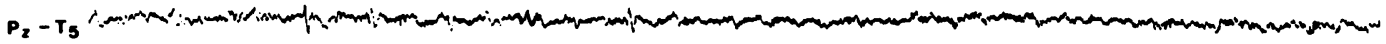


ticular, is only symptomatic and is restricted to cases of toxic confusion showing irritative EEGdischarges. In in vitro studies benzodiazepines have been shown to suppress effectively the increased excitability induced by several neuroleptics. ${ }^{26}$ This prominent relief of electroclinical dysfunction following benzodiazepine administration has not yet been reported in clinical toxic conditions. ${ }^{27}$ However, recovery can only be complete and permanent if the offending drug or combination of drugs is withdrawn. The condition does not necessitate sustained anti-epileptic drug treatment.

\section{References}

' Strub RL. Acute confusional state. In: Benson DF and Blumer D, eds. Psychiatric Aspects of Neurologic Disease. New York, Grune \& Stratton, 1982:1-23.

${ }^{2}$ Schwartz MS, Scott DF. Isolated petit mal status presenting de novo in middle age. Lancet 1971;2:1399-401.

${ }^{3}$ Ellis JM, Lee SI. Acute prolonged confusion in later life as an ictal state. Epilepsia 1978;19:119-28.

4 Terzano MG, Gemignani F, Mancia D. Petit mal status with myoclonus: case report. Epilepsia 1978; 19:385-92.

s Aguglia U, Tinuper P, Farnarier G. Etat confusionnel critique prolongé à point de départ frontal chez un sujet agé. Rev Electroencephalogr Clin Neurophysiol 1983;13:174-9.

${ }^{6}$ Pro JD, Wells CE. The use of the electroencephalogram in the diagnosis of delirium. Dis Nerv Syst 1977;38:804-8.

7 Obrecht R, Okhomina FOA, Scott DF. Value of EEG in acute confusional states. J Neurol Neurosurg Psychiatry 1979;42:75-77.

${ }^{8}$ Sweden B van, Hoste S. Periodic EEG-discharges in psychiatry. Eur Neurol 1983;22:359-66.

${ }^{9}$ Gloor P. Generalised and widespread bilateral paroxysmal activities. In: Cobb WA, ed. Handbook of EEG and Clinical Neurophysiology. Amsterdam, Elsevier 1976: Vol 11 part B. EEG-interpretation in clinical medicine, 52-87.

10 Thompson SW, Greenhouse AH. Petit mal status in adults. Ann Int Med 1968;68:1271-9.

$"$ Amand G. Etats d'absence et états confusionnnels prolongés au delà de 60 ans. Rev Electroencephalogr Clin
Neurophysiol 1971;1:221-3.

12 Heatfield KWG. Isolated petit mal status presenting de novo in middle age. Lancet 1972;1:492.

${ }^{13}$ Gall M van, Scollo-Lavizzari G, Becker H. Absence status in the adult. Eur Neurol 1978;17:121-8.

${ }^{14}$ Goldman JW, Glatstein G, Adams AH. Adult onset absence status: a report of six cases. Clin Electroencephalogr 1981;12:199-204.

15 Gibberd FB. Petit mal status presenting in middle age. Lancet 1972;1:269.

${ }^{16}$ Chatrian GE, Shaw C, Leffman $\mathrm{H}$. The significance of periodic lateralised epileptiform discharges in EEG: an electrographic, clinical and pathological study. Electroencēpholgr Clin Neurophysiol 1964;17:17793.

17 Schwarz MS, Prior PF, Scott DF. The occurrence and evolution in the EEG of a lateralized periodic phenomenon. Brain 1973;96:613-22.

${ }^{18}$ Bauer G, Aichner F, Hengl W. Der diagnostische Wert periodischer lateralisierter Komplexe im EEG. $Z$ EEG-EMG 1981;12:135-41.

${ }^{19}$ Schulze B. Zur Frage medikamentösinduzierter cerebraler Reaktionen: Ein Fall von myoklonischen Status unter Behandlung mit tricyclischen Antidepressiva. Nervenarzt 1972;43:332-6.

${ }^{20}$ Lippman S, Moskovitz R, O'Tuama L. Tricyclic-induced myoclonus. Am J Psychiatry 1977;134:90-91.

${ }^{21}$ Mellerio F, Levy-Alcover MA. Myoclonies d'origine toxique. Rev Electroencephalogr Clin Neurophysiolo 1982;12:210-8.

${ }^{22}$ Sweden B van. Neuroleptic neurotoxicity. Electroclinica aspects. Acta Neurol Scand 1984;69, 3:137-46.

${ }^{23}$ Westheimer R, Klawans HL. The role of serotonin in the pathophysiology of myoclonic seizures associated witho acute imipramine toxicity. Neurology (Minneap) 1974;24:1175-77.

${ }^{24}$ Burks JS, Walker JE, Rumack BH, Ott JE. Tricyclicê antidepressant poisoning. Reversal of coma, choreoathetosis and myoclonus by physostigmine. JAMA 1974; 230:1405-7.

${ }^{25}$ Holinger PC, Klawans HL. Reversal of tricyclicoverdosage-induced central anticholinergic syndrome by physostigmine. Am J Psychiatry 1976;133:101823.

${ }^{26}$ Oliver AP, Luchins DJ, Wyatt RJ. Neuroleptic-induced seizures. Arch Gen Psychiatry 1982;39:206-9.

${ }^{27}$ Overweg J, Binnie CD. Benzodiazepines in neurological disorders. In: Costa $\mathrm{E}$, ed. The Benzodiazepines. New York Raven Press, 1983:339-49. 